\title{
Novels Speak Reality: Ivanhoe, An Example
}

\author{
Roy Xavier T \\ M.A., M.Phil. \\ Researcher (Ph D)-English \\ Bharathiar University \\ Coimbatore, Tamil Nadu, India \\ roytxavier@gmail.com
}

\begin{abstract}
Stories have been the source of moral lessons and entertainment, as far as the humankind of all the time, is concerned. The use of story- telling existed from the time immemorial. Stories appeared in the form of ballads and epics, in the ancient time, but later it took the shape of short and long fictions. The long fictions or novels varied in its theme and size. They are divided into many genres according to its subject matter- Gothic, Picaresque, Historical etc. The Ballad is nothing but a short story in verse. Its subjects are simple and memorable like adventure, love, war and the life etc. An Epic is a long tale in verse with famous heroes for its main characters. Iliad and Odyssey are examples. These stories gave the reader enjoyment and certain life-related 'tips'. Hayden White, an American historian says, "the aim of the writer of a novel must be the same as that of the writer of the history". Historians and Novelists wish to provide a verbal image of 'reality'. A novelist may produce reality indirectly but this is meant to correspond to some sphere of human experience. He desires to pass the merits and demerits of such experience onto the readers, to enhance a better vision of life. Novelists are free to use fictitious characters and situations for the readers' entertainment. Stories took its present prose form later in the middle ages. Decameron, a
\end{abstract}


collection of stories by Boccaccio, was published in 1350. It deals with stories told by a group of people affected by Black Plague. They used these stories to get mental relief from the pandemic. 'Canterbury Tales' of Geoffrey Chaucer also, is telling the life-related stories by some pilgrims to the shrine of St. Thomas Becket at Canterbury. All these show that men were, from the early ages itself, used to tell stories to recollect the past and go forward with lessons of reality for a better life. Actually these stories are 'historical facts' blended with the imagination of the writers.

The year 1719 marked the beginning of the long fictions ie, Novels in English, with the publication of Robinson Crusoe of Daniel Defoe. It tells the story of a young navigator, Robinson Crusoe and his experience with navigation, exploration, alienation etc. The story tells the facts connected to the view of the man of the $17^{\text {th }}$ century, towards the relation between man and nature that 'sprang from the depths of the English middle class view of life' (R.C p 2). And also, it is a real picture of the then European people of their exploration through seas and oceans to distant lands for business and invasions. They wanted to discover new lands and sources for making money and increase their material comforts. A reader of the novel comes to know the spirit of expedition and adventure of the $17^{\text {th }}$ century English men. 'Robison Crusoe' is considered to be a true history because it was published to appear not as 'fiction', but as a chronicle of real events. But towards the end of the $18^{\text {th }}$ century, such fictions were started to be called as 'novel'. 'Robinson Crusoe' is the first of its kind and so the year 2019 marked the $300^{\text {th }}$ anniversary of the publication of the first English novel. We, thus, come to know that the very nature of any novel is nothing but narrating about something real or historical, in a fictitious manner.

After a century of the publication of the first novel in English, Robinson Crusoe, the novel Ivanhoe came in the year 1819. Ivanhoe marked the beginning of a new genre in the field of Novels, called Historical Novel. It was written by Sir Walter Scott, the 'Father of 
historical novel' in English literature. It was published as his tenth novel in the 'Waverly' series. The historicity or the authenticity of Ivanhoe, as a Historical Novel, is strongly attached to the life and nature of Sir Walter Scott. Scott was born on the $15^{\text {th }}$ of August 1771 , in Edinburg. His father was a lawyer and his mother Anne Rutherford was a woman of imagination and wonderful memory. She was full of stories and legends and remained a source of Scott as a novelist. Scott's genius derived much from his mother. Owing to his infantile paralysis, Scott was lame for the whole life. He spent much of his boyhood at his grandfather's farm at Sandy Knowe, in one of the border counties of Scotland. It contained many relics of the old historic days. Here, he heard from his grandmother and old shepherds the exciting tales of border raids and expedition of many heroes. Scott got opportunity to listen to the songs and ballads of the old days of fighting between the Scots and Englishmen. This historic past remained imprinted in his memory. Scott was thus from his earliest days, steeped in the history of his country and in the sense of the past. His mother, grandparents and the surroundings of his childhood life created in him a sense of history. He said, "To the Romances and Poetry I chiefly delighted in I had always added the study of history, especially as connected with military events"(IH p.vi). His life and knowledge made him a famous writer in English especially in the genre of Historical novel. Sir Walter Scott died on 21, September 1832 and his famous house 'Abbotsford' remain till today as the veritable museum of rare antiques.

Sir Walter Scott, being a native of Scotland had been writing historical novels based on the history of Scotland. But the tenth novel of his Waverly series , 'Ivanhoe' came out with the history of England. This novel made him world famous. There are so many references to the history and legends of England, in the novel. The title 'Ivanhoe' is taken from an ancient ballad which narrates about the conflict between two nobles in England. When we look into the history of England, the aptness of the title becomes clearer. It is 
because England held a past in which the two races, Normans and Saxons fought for centuries. By the end of the $5^{\text {th }}$ century or so, the Romans lost their grip on England and its natives, the Britons. Germanic and Scandinavians invaded England and became owners, rulers and natives of England. They intermarried with the Britons and became the permanent natives of England and they were known as Anglo-Saxons or Saxons. In 1066, William the conqueror of Normandy, France conquered England and became the ruler of England. Now the Saxons lost their power and even their culture became obsolete. Antagonism between the Saxons and Normans grew. Ivanhoe, the main character, is a Saxon but he was much loyal to the King Richard, who was a Norman. The novel, Ivanhoe deals with the antagonism between the Saxons and the Normans.

Ivanhoe is set in the $12^{\text {th }}$ century England when Richard, the Lion hearted was the ruler. He was the Norman, who ruled England from 1189 till his death in 1199 . He was the central figure during the Third crusade between 1189 -1192. His most noted victory was against Saladin, the Muslim leader during the Third Crusade. King Richard is a main character in the novel. And another character is his brother prince John who played spoilsport to come to power during the absence of King Richard, who was in the Crusade and in Austria as a captive. Anyway John became the king of England after the death of his brother King Richard in 1199 and he ruled till his death in 1216. These historical facts are coming in the novel, directly or indirectly. Prince John appears in the novel as a person who tortured the Saxons. He takes the help of Sir Brian de Boi-Guilbert and Albert Malvoisin. Sir Walter Scott leaves no stone unturned in revealing the racial, cultural, political and linguistic antagonism between the Saxons and the Normans. He deploys a wide range of characters of about sixty, of which a dozen hold key roles. The story reveals the hypocrisy of the Knight Templars like, Maurice de Bracy and Boi Guilbert. They become opportunistic and go 
courting the heroines Rowena and Rebecca. All these Normans are conspiring and acting against the Saxons.

The important Saxon characters include Cedric of Rotherwood, a typical patriot who loves to have Saxon rule in the country. He is opposed to the Normans and he dreams to establish the confederacy of Saxons under Athelstane, Lord of Coningsburh and the Saxon of royal descent. He was betrothed his ward Lady Rowena, another descendant of the Saxon kings, to be married to Athelstane. Cedric disinherited his son, Knight Wilfred of Ivanhoe because he joined the Norman King Richard and also for being in love with Rowena who loves Ivanhoe in return. The name Cedric can be associated with the name of Cerdic who was a Saxon king who ruled England after the Romans had left the country. Ivanhoe is a name which can be traced in ancient ballad which describes about the conflict between two nobles in England. Sir Walter Scott has rightly chosen this name as the title as well the name of the hero of the story. Isaac and his daughter Rebecca are the other two characters in the novel. They are Jews who were looked down by both Saxons and Normans. They are aptly brought to light in the novel to show the real attitude of others to Jews and the place they occupied in the then society in England. Robin Hood, whose name is taken from the English legend, is another character in the novel.

Ivanhoe, set in the 12th century England, brings characters of historical and legendary past of England. The crusades, duals, conflicts, archery match, romantic settings etc. recreate history. At the end of the story, we see that on the persuasion of King Richard, Cedric is reconciled with his son, Ivanhoe and Athelstane surrenders his claim on Rowena who is united with Ivanhoe. Being isolated, Prince John bows down before his brother King Richard, under whose rule Normans and Saxons lived amicably. Rebecca, suppressing her love for Ivanhoe, leaves England with her father Isaac because she finds the country unbearable for Jews. 
The novel, Ivanhoe acquired wide popularity due to its happy ending. Scott has taken wisely the real and legendary past of England to mould his novel to be the best Historical Romance the world has ever seen. Despite so many differences of opinions and other internal controversies, a nation must stand strong for its people. Scott wanted to see the people of England united and peace loving. He took persons, legends and incidents from history and tied them in the 'thread of Nationalism' according to his view of the world. A British author W.H Hudson says, "directly or indirectly, and whether the writer himself is conscious of it or not, every novel must necessarily present a certain view of life and of some of the problems of life; that is, it must so exhibit incidents, characters, passions, motives as to reveal more or less distinctly the way in which the author looks out upon the world and his general attitude towards it"(BSEL p195). Sir Walter Scott has made this novel a wonderful creation with his view of the World and England, in particular!

Abbreviations used:

R.C : Robinson Crusoe

IH : Ivanhoe

BSEL : A Background to the Study of English Literature. 


\section{References}

Scott Walter Sir, Ivanhoe, UBS Publishers, Distributors Pvt. Ltd.

PRASAD B , A Background to The Study of English Literature, Macmillan India Limited RAVEENDRAN P P , Texts Histories Geographies: Reading Indian Literature, Orient Blackswan Private Limited. 